\title{
Cognitive approach to the analysis of innovative and investment potential of the region
}

\author{
Alexey Gennadievich Zaytsev \\ FSBEI HE "Orel State University \\ named after I.S. Turgenev" \\ Institute of Economics and Management \\ Orel, Russia \\ cbap@bk.ru
}

\author{
Maria Alexandrovna Vlasova \\ FSBEI HE “Orel State University \\ named after I.S. Turgenev" \\ Institute of Economics and Management \\ Orel, Russia \\ docent-ostu@yandex.ru
}

\author{
Petr Nikolaevich Mashegov \\ FSBEI HE "Orel State University \\ named after I.S. Turgenev" \\ Institute of Economics and Management \\ Orel, Russia \\ yand-man@yandex.ru
}

\begin{abstract}
The article considers different approaches to the analysis and modeling of innovative and investment attractiveness of regions. The authors compared the traditional methods in the form of ranking and positioning of the region based on the aggregation of groups of indicators and the method of constructing cognitive maps. The limitations which imposed on the modeling and presentation of results while using these two groups of methods have been considered. The compromise approach that combines the advantages of formal and cognitive methods of analyzing the regions' innovation and investment attractiveness is formulated.
\end{abstract}

Keywords - innovations, investments, region, cognitive analysis, potential of the region

\section{INTRODUCTION}

Innovation and investment attractiveness of the region is the basis for taking investment decision and determines the consequences for both the investor and the macroeconomy in general. The more complex the situation, the better experience and intuition of the investor should be build on the results of the expert assessment of investment attractiveness at the level of the regional economy [1]. Of particular note is that more often the investment component is considered explicitly as an opportunity to achieve the investor's strategic goals (profit, risks, etc.), while innovation component is considered only as one of the factors of the region's potential. This approach is rational, first of all, from the standpoint of private nonstrategic investor. If the task is to consider the interests of the region's development and long-term investment, the issues of long-term development and the innovative component begin to play more significant role and make it necessary to consider the broader concept, namely the innovation and investment potential of the region.
The innovation and investment attractiveness of the region is a combination of various objective features, means, opportunities and restrictions that determine the investments attraction intensity in the region's economy, the perception of which varies significantly depending on the subjective attitudes of one or another investor. In other words, it is not competent to consider the investor's choice, and, consequently, the innovative investment potential value, either purely objective (based on formalized indicators) or purely subjective (based solely on the prospective investor's intuition).

Its level is determined by several factors, among which are:

- the efficiency of the economy, expressed in the growth of GDP and the degree of local authorities interest in the activities of particular investor;

- the growth potential and the expected level of market liquidity, financial exposure in the current and strategic planning horizon;

- the utility of the object, namely, the ability to achieve goals that go beyond the planned return on investment and which has the effective demand;

- the availability of various types of infrastructure, including innovation one, and the ability to recruit staff with the required skills.

In a general manner, the innovation and investment attractiveness of the regions is a system of relations that are formed under the influence of a wide range of interrelated processes and the set of conditions for investment activity.

The conditions of investment activity are characterized by factors of political, socio-psychological, financial and economic, legislative, regulatory, environmental, criminal, resource-based, production, innovation, labor, infrastructure, consumer and institutional character. 
These factors reflect both the objective capabilities of the region to develop and expand investment activities, and the conditions for investor activities (investment risk), create prerequisites for the emergence of sustainable investment motivations, have a significant impact on investment returns and the level of investment risks, and determine the appropriateness and efficiency of investment.

The approach to the study of investment attractiveness under consideration makes it possible to solve the question of validity of the methods for defining the levels of investment appeal in the regions of the Russian Federation and the reliability of the results obtained with its help. The composition of the individual factors of the investment potential and investment risk of the region, the weighting coefficients of the significance of particular factors and the method of their integration (with the inclusion of particular factors in the calculation of the integral indicator - the level of the region's investment attractiveness) should be selected taking into account all the essential components of investment attractiveness (while meeting the principle of necessity and sufficiency).

\section{MATERIALS AND MethodS (MODEL)}

The methodology for the formation and structure of indicators of the best known ratings of innovation and investment attractiveness of Russian regions was analyzed and the corresponding conclusions were drawn. Including, such as, the Rating of Investment Attractiveness of Russian Regions of "RAEX-Analytics" company and the Rating of Innovative Regions of "Association of Innovative Regions of Russia", as well as the rating of the Russian Federation constituent entities by future preparedness index value.

The correlation analysis of the relationship between the indicators characterizing the innovative and investment attractiveness of a number of regions of the Central Federal District over the past four years was conducted.

The methodology for constructing cognitive maps of the innovation and investment potential of the region is proposed. It combines traditional methods of constructing cognitive maps based on expert opinions and formalized approaches to determining the nature and intensity of the relationship between elements of the cognitive map.

\section{RESULTS AND DISCUSSION}

The analysis of the methodologies for compiling the following ratings: the Rating of Innovative Regions of "Association of Innovative Regions of Russia" [2]; the rating of the territorial entities of the Russian Federation by future preparedness index value [3] (which can be viewed as a combined rating of innovation and investment attractiveness and regional business climate), as well as the Rating of Investment Attractiveness of "RAEX-Analytics" company has shown that they are all formed according to the similar methodology, which is summarized below.

The evaluation of the innovative and investment attractiveness of the Russian Federation regions includes the study of the investment market, the choice of factors that influence both the regions themselves and the investment policy inside them. Conditionally, such modeling can be divided into five stages.

Stage 1. Analysis of innovation and investment markets and creation a system of indicators to assess the degree of attractiveness of Russian regions.

Stage 2. Determination of innovative and investment attractiveness level of regions on the basis of the formed system of indicators by modeling using regression analysis methods.

Stage 3. Allocation of investment attractive regions from a set of regions of homogeneous groups with the help of cluster analysis. Determination of the representative in each group. Use of economic and statistical analysis to study the factors that have significant impact on the innovative and investment attractiveness of homogeneous group of regions.

Stage 4. Construction and investigation of innovation and investment attractiveness regressive models.

Stage 5. Assessment of regions taking into account the predictions of the identified main factors.

The subjective nature of investors' perception of certain indicators (elements of innovation and investment potential) of the region is realized through the use of weighting coefficients in aggregation to calculate the value of which the method of peer review is used. Thus, when compiling the RAEXAnalytics rating, the value of expert weights of private types of potentials is calculated based on the results of an annual survey of Russian and foreign experts and investors conducted in the three-month period preceding the release date of the rating[4].

The multidimensional mean method is used as a method of integrating the numerical values of particular indicators characterizing the investment attractiveness of the region:

$$
\text { ИП }_{j}=\frac{\sum_{i=1}^{n} k_{i} \cdot \frac{P_{i j}}{\overline{P_{i}}}}{\sum_{i=1}^{n} k_{i}}
$$

where ИП $j$ is an integral level of innovative and investment attractiveness of the $j$ - region; $i$ is a partial indicator; $n$ is the number of reducible partial indicators; $\mathrm{k}_{\mathrm{i}}$ is the weighting coefficient of the $\mathrm{i}$ - index; $\mathrm{P}_{\mathrm{ij}}$ is the numerical value of the $\mathrm{i}$ - index for the $\mathrm{j}$ - region; $\bar{P}_{i}$ is the numerical value of the $\mathrm{i}$ - index in the average across Russia.

The considered formalized approach, providing a fairly objective picture in general, but is rather conservative in terms of consideration for the unevenness of the role of individual indicators and their significance for specific groups of investors. It does not allow modeling and tracing the development trajectories of specific regions in the dynamics, that is, fixing the rating change is possible only with respect to the coordinates of other regions, and the general market dynamics is ignored. The movement of regions in the ranking 
is similar to the movement of boats on the river relative to each other, while the general trend of the development of the region that is important for decision-making can not be understood without taking into account the current (general market trend), which is recorded only relative to the coast (a coordinate system that goes beyond the rating).

Currently, the methods of modeling the innovation and investment attractiveness of the region based on the use of cognitive maps are gaining popularity. Of particular note was the fundamental work on this problem (Avdeeva Z.K., Kovriga S.V., 2011) [5] in which within the cognitive approach the main elements of building a cognitive map of the region's development were distributed and practical calculations of various scenarios for regional development were carried out. Similar methodological approaches are presented in the articles of D. G. Lagerev. [6], Palyukh B.V., Kakatunova T.V. [7]. It is significant that the methodology of compiling cognitive maps is well combined with the use of various methodical techniques, such as the use of fuzzy logic and others. The toolkit of cognitive maps is applicable both to the modeling of the development of the region as a whole and to certain areas related to its functioning, for example, the process of informatization [8] and even social institutions that have an indirect impact on the innovation and investment climate in the region [9]. There is experience in modeling the ratings of socio-economic development of regions based on the tools of cognitive maps [10].

Without debating the legitimacy of using the above methods, we note some features that make it difficult to use them.

First, the traditionally cognitive map is formed in the form of a graph with numerous connections. With a significant number of peaks, while the formation of the region's innovation and investment potential map requires consideration of a large number of elements, makes it difficult for the expert to perceive it and can lead to the fact that some significant links will be missed. In addition, with such a large number of elements, it is difficult to identify loops of mutual weakening and amplification, which are characteristic of innovative processes.

Secondly, the use of exclusively expert opinion in determining the nature of the relationship between the elements (the length of the graph edges), even with a significant number of experts, can lead to unfair assessment characterizing the interrelations between the elements of innovation and investment potential.

It is suggested to use the following techniques when drawing up a cognitive map of the region's innovation and investment potential to overcome these problems.

The first suggestion deals with the architecture of the cognitive map. It is necessary to structure the indicators that characterize the innovative and investment potential of the region in terms of levels, combining them into groups (clusters) as it is done when making ratings by classical methods. At least two levels will be present when drawing up a cognitive map of the innovation and investment potential of the region; however, depending on the complexity of the problem under consideration, there may be more of them. An expert characterizes the relationships between clusters or indicators within a cluster. If necessary, the same indicator can be included in several clusters, but the relationships between the indicators of different clusters (at the lower level) are not considered.

The second suggestion is related to the order of determining the strength of relationships (the length of the graph edges), which is determined on the basis of a comparison of the values obtained by the method of correlation analysis and expert judgments. There are several possible ways to implement this comparison: a) the final expert - the expert is introduced to the result of the correlation analysis, but his opinion is recorded into the map regardless of the formal value of the link; b) final formal - the expert characterizes the relationships not having the data of the correlation analysis, the correlation coefficients with the correction coefficient calculated on the basis of expert opinion on the previously agreed algorithm are recorded into the map; c) more complex schemes for combining formal and expert coefficients, including with different weights for different clusters.

As part of the study, the following nomenclature of clusters characterizing the risks and potentials (top level graph node) was adopted: production $(x 1)$, social and labor $(x 2)$, consumer $(x 3)$, natural resource $(x 4)$, intellectual $(x 5)$, infrastructure $(x 6)$, financial $(x 7)$, innovation $(x 8)$ and external economic $(x 9)$, financial costs $(x 10)$, social costs $(x 11)$ and environmental costs $(x 12)$.

Each cluster included a group of indicators that characterize it. Below are the indicators that are the graph nodes in some groups:

- Production capacity indicators - GRP total, mln. RUB; GRP per capita, RUB; Value of fixed assets of economic sectors (at full book value at year-end), mln. RUB; Number of enterprises and organizations (at year-end); Number of small enterprises (at year-end); The volume of industrial output (in actual prices), mln. RUB; Level of profitability of industrial enterprises and organizations assets, \%; Agricultural products, mln. RUB; The amount of work performed under construction contracts, mln. RUB; The launch of dwellings into use per 1 thsd. pers, sq. m. of total area;

- Infrastructure capacity indicators - Retail turnover per capita, RUB; Volume of paid services per capita, RUB; Shipment of goods by public railway, million tons; Road transportation, million tons; Density of public railway, $\mathrm{km}$ of railways per 10 thousand square $\mathrm{km}$ of territory; Density of public hard surface roads, $\mathrm{km}$ of roads per 1 thousand square $\mathrm{km}$ of territory

- Indicators of social costs - Number of unemployed, thsd. pers.; Unemployment rate, as percentage of economically active population; Morbidity per thsd. pers. of the population; Number of recorded crimes per 100 thsd. pers.of the population; Number of recorded murders and attempted murders 
Of particular note is that, if necessary, the statistical indicators included in the clusters can be supplemented by various indicators, estimated by expert means and synthetic indicators, for example, in the ranking of a wellknown rating agency.

Approbation was carried out on the statistical data of several regions in the Central Federal District for the last four years. Table 1 presents the elements of adjacency matrix for the first level of the cluster "Production capacity", obtained on the basis of the comparison of the correlation coefficients between the indicators and expert judgments using the "final formal" algorithm in which the expert opinion is formed regardless of the fixed correlation coefficient, and the final result (matrix value) is obtained by multiplying the indicators of strength of relationship obtained by different methods.

TABLE I. THE ELEMENTS OF ADJACENCY MATRIX FOR THE CLUSTER "PRODUCTION CAPACITY"

\begin{tabular}{|c|c|c|c|c|c|c|c|c|}
\hline & P1 & P2 & P3 & P4 & P5 & P6 & $\ldots$ & $P n$ \\
\hline P1 & & 0,39 & 0,02 & 0,25 & 0,15 & 0,23 & & \\
\hline P2 & 0,39 & & 0,12 & 0,45 & 0,28 & 0,37 & & \\
\hline P3 & 0,02 & 0,12 & & 0,02 & 0,27 & $-0,06$ & & \\
\hline P4 & 0,25 & 0,45 & 0,02 & & 0,13 & 0,81 & & \\
\hline P5 & 0,15 & 0,28 & 0,27 & 0,13 & & 0,04 & & \\
\hline P6 & 0,23 & 0,37 & $-0,06$ & 0,81 & 0,04 & & & \\
\hline .. & & & & & & & & \\
\hline$P n$ & & & & & & & & \\
\hline
\end{tabular}

Comparison of the assessment results for the CFD regions innovation and investment potentials obtained according to the classic methods of rating agencies and the proposed methodology showed coincidences (or minor discrepancies) with respect to the assessment of the relative innovation and investment potential of the regions, which demonstrates the comparability of the results and applicability of the proposed methodology. In addition, when attempting to conduct scenario analysis in the form of changing individual model parameters, the proposed method demonstrated a much higher sensitivity with respect to the final result in comparison with the classical one.

\section{CONCLUSION}

Thus, the analysis of the methodology for the formation and structure of indicators of the best known ratings of innovation and investment attractiveness of Russian regions was made in the present work. It showed that this method does not allow modeling and tracing the development trajectories of specific regions in the dynamics, that is, the fixation of the rating change is possible only with respect to the coordinates of other regions, and the general market dynamics is ignored.

To solve this problem, it is proposed to use methods for constructing cognitive maps. Upon that, the following approaches act as specific ones: a) proposal to structure the indicators that characterize the innovative and investment potential of the region by levels, combining them into groups (clusters) as it is done when making ratings by classical methods; b) determination of strength of relationship is identified on the basis of the values comparison obtained by the method of correlation analysis and expert opinions.

The set of the proposed methods, on the one hand, demonstrates sufficiently high convergence with the results of classical assessment of innovative and investment potential of regions, and, on the other hand, demonstrates higher sensitivity of the final result when the value of the key elements of the potential changes.

\section{References}

[1] Guskov, I.S. Investments. Forms and methods of their attraction / I.S. Guskov, I.V. Zenyakin, V.V. Kryukov, V.A. Shershunov. - M.: Algorithm, 2001 [Gus'kov, I.S. Investitsii. Formy i metody ikh privlecheniya / I.S. Gus'kov, I.V. Zenyakin, V.V. Kryukov, V.A. Shershunov. - M :. Algoritm, 2001] Гуськов, И.С. Инвестиции. Формы и методы их привлечения / И.С. Гуськов, И.В. Зенякин, В.В. Крюков, В.А. Шершунов. - М.: Алгоритм, 2001

[2] Rating of innovative regions // Association of Innovative Regions of Russia URL: http://i-regions.org/regions/proekty/rejtinginnovatsionnogo-razvitiya [Reiting innovatsionnykh regionov // Assotsiatsiya innovatsionnykh regionov Rossii URL: http://iregions.org/regions/proekty/rejting-innovatsionnogo-razvitiya] Рейтинг инновационных регионов // Ассоциация инновационных регионов России URL: http://i-regions.org/regions/proekty/rejtinginnovatsionnogo-razvitiya

[3] The rating of innovative development of the subjects of the Russian Federation. Issue 5 / GI Abdrakhmanova, P.D. Bakhtin, L.M. Gokhberg and others; Ed. L. M. Gokhberg; Nat. Issled. University Higher School of Economics. - Moscow: NIU HSE, 2017. - 260 p [Reiting innovatsionnogo razvitiya sub"ektov Rossiiskoi Federatsii. Vypusk 5 / G. I. Abdrakhmanova, P35 P. D. Bakhtin, L. M. Gokhberg i dr.; pod red. L. M. Gokhberga; Nats. issled. un-t «Vysshaya shkola ekonomiki». - M.: NIU VShE, 2017. - 260 s] Рейтинг инновационного развития субъектов Российской Федерации. Выпуск 5 / Г. И. Абдрахманова, П. Д. Бахтин, Л. М. Гохберг и др.; под ред. Л. М. Гохберга; Нац. исслед. ун-т «Высшая школа экономики». - М.: НИУ ВШЭ, 2017. $260 \mathrm{c}$

[4] Method of drawing up a rating of the investment attractiveness of the regions of Russia by RAEX-Analytics https://raexpert.ru/docbank//109/d31/3e8/5564b5d35605a92af9b47c6.pdf [Metodika sostavleniya reitinga investitsionnoi privlekatel'nosti regionov Rossii kompanii «RAEKS-Analitika»

https://raexpert.ru/docbank//109/d31/3e8/5564b5d35605a92af9b47c6.pdf]

Методика составления рейтинга инвестиционной привлекательности регионов России компании «РАЭКС-Аналитика» // https://raexpert.ru/docbank//109/d31/3e8/5564b5d35605a92af9b47c6.pdf

[5] Avdeeva Z.K., Kovriga S.V. Formation of a strategy for the development of socio-economic facilities based on cognitive maps. Saarbrucken: LAP LAMBERT Academic Publishing GmbH \& Co. KG KG, 2011. - P. 184 $\mathrm{http} / / / \mathrm{www} . \mathrm{mtas} . \mathrm{ru} / \mathrm{search} / \mathrm{search}$ results.php?publication_id=18846 [Avdeeva Z.K., Kovriga S.V. Formirovanie strategii razvitiya sotsial'no-ekonomicheskikh ob"ektov na osnove kognitivnykh kart. Saarbrucken: LAP LAMBERT Academic Publishing $\mathrm{GmbH} \&$ Co. KG, 2011. - S. 184 http://www.mtas.ru/search/search_results.php?publication_id=18846] Авдеева 3.К., Коврига С.В. Формирование стратегии развития социальноэкономических объектов на основе когнитивных карт. Saarbrucken: LAP LAMBERT Academic Publishing GmbH \& Co. KG, 2011. - C. 184 http://www.mtas.ru/search/search_results.php?publication_id=18846

[6] Lagerev D.G. Use of fuzzy cognitive maps for determining promising ways to increase the effectiveness of the scientific potential of the region // http://www.tu-bryansk.ru/doc/np/lagerevDG.pdf [Lagerev D.G. Ispol'zovanie nechetkikh kognitivnykh kart dlya opredeleniya perspektivnykh putei povysheniya effektivnosti nauchnogo potentsiala regiona // http://www.tubryansk.ru/doc/np/lagerevDG.pdf] Лагерев Д.Г. Использование нечетких когнитивных карт для определения перспективных путей повышения 
эффективности научного потенциала региона // http://www.tubryansk.ru/doc/np/lagerevDG.pdf

[7] Palyukh B.V., Kakatunova T.V. Fuzzy cognitive map as a tool for modeling innovation activity at the regional level // Software products and systems No. 4. - 2012. - P. 128 - 132 [Palyukh B.V., Kakatunova T.V. Nechetkaya kognitivnaya karta kak instrument modelirovaniya innovatsionnoi deyatel'nosti na regional'nom urovne // Programmnye produkty i sistemy № 4. - 2012. - S. 128 - 132] Палюх Б.В., Какатунова Т.В. Нечеткая когнитивная карта как инструмент моделирования инновационной деятельности на региональном уровне // Программные продукты и системы № 4. - 2012. - С. 128 132

[8] Gulmamedov R.G. Cognitive map for the analysis of problems of regional informatization // Business Informatics №2 (20). - 2012. - P. 65 - 70 https://bijournal.hse.ru/data/2012/09/17/1245162787/9.pdf [Gyul'mamedov R.G. Kognitivnaya karta dlya analiza problem regional'noi informatizatsii // Biznes-informatika №2 (20). - 2012. - S. 65 - 70 https://bijournal.hse.ru/data/2012/09/17/1245162787/9.pdf] Гюльмамедов Р.Г. Когнитивная карта для анализа проблем региональной информатизации // Бизнес-информатика №2 (20). - 2012. - С. 65 - 70 https://bijournal.hse.ru/data/2012/09/17/1245162787/9.pdf
[9] Machueva D.A. Fuzzy cognitive map for assessing the effectiveness of the judicial system / / Fundamental research. - 2016. - No. 4-3. - P. 517 522; URL: https://fundamental-research.ru/en/article/view?id=40208 [Machueva D.A. Nechetkaya kognitivnaya karta dlya otsenki effektivnosti sudebnoi sistemy // Fundamental'nye issledovaniya. 2016. - № 4-3. - S. 517-522; URL: https://fundamentalresearch.ru/ru/article/view?id=40208] Мачуева Д.А. Нечеткая когнитивная карта для оценки эффективности судебной системы // Фундаментальные исследования. - 2016. - № 4-3. - С. 517-522; URL: https://fundamental-research.ru/ru/article/view?id=40208

[10] Lavrash I.I., Mironov V.V., Smirnov A.V. Cognitive modeling of socioeconomic ratings of regions // Vestnik ITARK. - 2011. - №1. - C. 22 - 31 URL: http://vvfauzer.ru/lab/smirnov/Cognitive_Modeling.pdf [Lavresh I.I., Mironov V.V., Smirnov A.V. Kognitivnoe modelirovanie sotsial'no-ekonomicheskikh reitingov regionov // Vestnik ITARK. - 2011. - №1. - S. 22 - 31 URL: http://vvfauzer.ru/lab/smirnov/Cognitive_Modeling.pdf] Лавреш И.И., Миронов В.В., Смирнов А.В. Когнитивное моделирование социальноэкономических рейтингов регионов // Вестник ИТАРК. - 2011. - №1. - С 22 - 31 URL: http://vvfauzer.ru/lab/smirnov/Cognitive_Modeling.pdf 